\title{
CHINESE WOMEN IN THE LATE QING PERIOD: READING THROUGH GUIDO AMEDEO VITALE'S CHINESE FOLKLORE: PEKINESE RHYMES
}

\section{Introduction}

Language incorporates social values. Gender bias is deeply rooted in the Chinese language, reflecting not only men's attitudes towards women, but also the unfathomable adversity that women have faced within Chinese society. For example, metaphors containing 虎 ( b̌̌ ' 'tiger' assume negative connotations for women while presenting men positively. ${ }^{1}$ More specifically, the semantic molecules of tiger (animal, powerful, and violent) in Chinese are not considered womanly characteristics, but are seen as characteristics of men. In other words, sex is the only crucial variable in this semantic system ${ }^{2}$ and in the semantic derogation of women. ${ }^{3}$

In the past, the Confucian ideals of harmony and order held that a good Chinese woman should obey the Three Obediences and Four Virtues: "The Three Obediences seek to give stricture to the entirety of a woman's existence, and accordingly state that the woman, in her youth, should be obedient to her father and her older brothers; in married life, she should be obedient to her husband; and as a widow she should be obedient to her son. The Four Virtues, on the other hand, impart rules of propriety, whereby a woman may be able to govern her life and her conduct. The first virtue is the ability of a woman to know and adhere to a submissive place in society and to modulate her behavior accordingly. The second virtue consists of restraining speech, since a talkative woman is not only considered impolite but even tiresome. The third virtue instructs a woman to dress and adorn herself in order to please a man. The last virtue states that a woman must know the proper management of her household and she must cheerfully do all the work needed in the home". 4

ORCID: 0000-0002-8961-4177, DOI: 10.4467/23538724GS.20.049.13489

1 S.-F. Chen, L.-C. Chen, What animals reveal about grammar and culture: $A$ study of animal metaphors in Mandarin Chinese and English, "Journal of National Taiwan Normal University: Linguistics and Literature” 2011, vol. 56, no. 2, pp. 121-152.

2 D. Spender, Man Made Language, London 1998.

3 M. Schulz, The semantic derogation of women [in:] Language and Sex: Difference and Dominance, eds. B. Thorne, N. Henley, Rowley, MA, 1975, pp. 64-75.

4 Berkshire Encyclopedia of China: Modern and Historic Views of the World's Newest and Oldest Global Power, ed. L. Cheng, Great Barrington, MA 2009, p. 2260. 
While the ideas of Confucian patriarchy retained their power in the minds of Chinese people for thousands of years, the subordination of Chinese women was greatly reinforced during the Qing dynasty (1644-1911), as evidenced in the widespread practices of foot-binding, prostitution, concubinage, female infanticide, as well as the social pressures placed on widows to remain chaste in memory of their deceased husbands. ${ }^{5}$ On the other hand, there was also an increase in female literacy. ${ }^{6}$ Women in the Qing dynasty were not just expected to adhere to the ideals of Confucianism, they also transformed Confucius's teachings through everyday practices in an attempt to empower themselves by creating personal and meaningful worlds in the inner quarters of their homes. ${ }^{7}$

The many different roles and functions of Chinese women, as well as their struggles in their everyday lives, have been analyzed in various disciplines. However, the representation of Chinese women in literature has barely been studied. Folklore, as a genre of literature, often shows how people lived historically, including "the traditional elements of the way of life of a group of people and the creative expressions developing naturally as a part of this way of life." 8 In particular, this genre often displays the lifestyles of those from the lower social classes. Propp defined folklore as "first and foremost, the art of the oppressed classes, both peasants and workers, but also of the intermediate strata that gravitate toward the lower social classes." In other words, the influence of Confucius's teachings on the lower social classes was not as great as it was on the middle and upper social classes. This perhaps indicates that women in the lower social classes did not always adhere to the Three Obediences and Four Virtues.

Although few improvements for women were seen when the Qing dynasty first began, a new Chinese feminism emerged later on in 1898 with the 103-day Wuxu Reform Movement. ${ }^{10}$ The reformist movement also brought an end to the ritual of foot-binding, which was outlawed in $1902 .{ }^{11}$ By 1876 , there were already up to

5 P.S. Ropp, The seeds of change: Reflections on the condition of women in the early and mid-Ch'ing, "Signs: Journal of Women in Culture and Society" 1976, vol. 2, no. 1, pp. 5-23; B. Grant, Patterns of female religious experience in Qing dynasty popular literature, "Journal of Chinese Religions" 1995, vol. 23 , no. 1 , pp. $29-58$.

6 Ibidem.

7 Z. Lin, Self-Representation and Female Agency in Qing China: Genteel Women's Writings on Their Everyday Practices in the Inner Quarters, doctoral dissertation, Hong Kong Baptist University 2018.

8 J.F. Putnam, Folklore: A key to cultural understanding, "Educational Leadership" 1964, vol. 21, no. 6, pp. 364-368.

9 V. Propp, Theory and History of Folklore (Theory and History of Literature, vol. 5), Minneapolis, MN 1984, p. 5.

10 Fang Zuyou 方祖猷，《晚清女权史》(The History of Feminism during the Late Qing Dynasty), Hangzhou 2017.

11 Y. Li, Women's movement and change of women's status in China, "Journal of International Women's Studies" 2000, vol. 1, no. 1, pp. 30-40. 
121 Church schools for the education of Chinese women with more than 2,100 students studying in them. ${ }^{12}$ Although, in the beginning, the Church schools focused on training these young Chinese women to do needlework or embroidery, rather than cultivating their reading and writing skills, at a later stage, they focused more on cultivating female independence. ${ }^{13}$ Thus, the role of women during the late Qing period remains extremely interesting, as the Chinese society of that time was like a melting pot, incorporating the ideals of feminism into traditional Chinese social values. In light of this, we can find examples of writing dealing with the phenomenon of a wife having an affair with another man or that of a man fearing his wife in the Chinese folklore of this period.

\section{Guido Amedeo Vitale and his Chinese Folklore: Pekinese Rhymes ${ }^{14}$}

Guido Amedeo Vitale's (1872-1918) Chinese Folklore: Pekinese Rhymes, first published in 1896, is a collection of 170 children's rhymes collected from the streets of Peking (Beijing) in the late Qing period. All the rhymes were translated into English and are accompanied by detailed notes.

After completing his studies in Istituto Universitario Orientale in Naples in 1893, Vitale served as an interpreter for the Italian Legation in Beijing. During this time, he developed an interest in Chinese folk songs and their possible use as a tool for teaching colloquial spoken Chinese to foreign students. In the late Qing period, the majority of Chinese intellectuals still regarded classical written Chinese as the only medium of artistic expression and songs in the colloquial language (báibua) sung by the ordinary people of Peking were deemed to be worthless and generally despised. ${ }^{15}$ This disregard of vernacular language resulted in a lack of understanding among Chinese intellectuals, which Vitale had to face while collecting and saving popular folk songs from oblivion. Even during the first years of the New Culture Movement in the 1910s, Vitale's contribution to Chinese folk studies was not widely acknowledged. The New Literature Movement, which was a part of the New Culture Movement, attempted to establish a new Chinese literature based solely on vernacular language, in strong opposition

\footnotetext{
12 Tan Shuangquan 谭双泉, 《教会大学在近现代中国》(Christian Colleges in Recent China), Changsha 1995, p. 194.

13 Fung Wai Sum 馮慧心, 〈近代女子教育發展探析: 從「賢妻良母」到現代新女性〉(On the development of women's education in recent China: From "dutiful wives and loving mothers” to new women in contemporary society), 《能仁學報》(Nang Yan Journal) 2018, vol. 16, pp. 117-130.

14 G. Vitale, Pekinese Baby-Songs, Hong Kong 1972 [1896].

15 C.-T. Hung, Going to the People: Chinese Intellectuals and Folk Literature, 1918-1937, Cambridge, MA 1985.
} 
to the classical literature of old imperial China. Since many of the young literati of that period were educated in Western countries, it was natural for them to accept the paradigms of Western poetry, but Chinese folk poetry was still not recognized as having poetic value. ${ }^{16}$ One of the first Chinese intellectuals who took notice of Vitale's work was Hu Shi, the 'father of Chinese poetry.' Hu Shi ${ }^{17}$ noted that songs collected by Vitale represented a natural and spontaneous style of people's poetry, and that many songs in the collection were examples of real poetry, rarely seen in the works of the new generation of poets and outside their studies on poetic composition.

In the preface to his work, Vitale himself describes the benefits that the reader may gain from the study of Pekinese children's rhymes as follows: 1) the acquirement of a small treasure of words and phrases hardly to be met with elsewhere; 2) a clearer insight into scenes and details of Chinese common life; 3) the notion that some true poetry may be found in Chinese popular songs. ${ }^{18}$ Thus, the presentation of Chinese people's common life was one of the main characteristics of Vitale's work. Due to the fact that most of the songs he collected were children's songs, they also clearly presented the lifestyles of women and children. Chinese Folklore: Pekinese Rhymes offers us a glance at the different stages of a woman's life in late Qing China. In the following subsections, how Chinese women were presented in these rhymes and songs will be illustrated and discussed.

\section{Discrimination against daughters}

In the framework of the traditional Chinese family, a daughter was regarded as being close to useless. While a son was expected to produce a male heir to continue the family line, a daughter would be married off and leave her natal family to become part of another. In Chinese Folklore: Pekinese Rhymes, No. CXII describes a small girl as being useless: ${ }^{19}$

$16 \mathrm{M}$. Yeh, A new orientation to poetry: The transition from traditional to modern, "Chinese Literature: Essays, Articles, Reviews” 1990, vol. 12, pp. 83-105.

$17 \mathrm{Hu}$ Shi 胡适, 〈北京的平民文学〉 (Peking literature of the people), 《胡适文存》(Writings of Hu Shi), vol. 4, Beijing 2013[1922], pp. 323-334.

18 G. Vitale, Pekinese Baby-Songs... p. vii.

19 As the English translation by Vitale contains some grammar and spelling mistakes, necessary corrections will be made. The grammar and spelling mistakes will be underlined, followed by the corrections in brackets. 
No. CXII, pp. 152-153

[口根]兒[口根]兒

上草垛

一年養活

七八個

好的都賣了

剩了秃頭

讓他刷缸

缸裹洗褲福

讓他刷鍋

鍋裹洗裹脚

讓他擦碟兒

碟裹洗面兒

讓他探地

崩到南邊兒看古穀地

看着穀葉兒黄

在上家裹去
The cock crowing - has jumped on the heap of grass - every year he bears seven or eight times - the good ones he has all sold - only a bald-headed (small) girl is left - if he lets her wash the vats - she washes there the bottom of the trowsers [trousers] - if he lets her wash the ricepot - she washes there her footbands - if he lets her wash the saucers - she washes her face in the saucers - if he lets her sweep the ground she runs away towards the South [south] to look at the grain fields - when she has seen that the grain is yellow - she comes back home.

The song starts with a cock crowing. However, in reality, the song is about a bald-headed small girl who stayed with her family because no one wanted to buy her. While her only function in the family is to do household chores, she does not do them very well. In brief, this song mocks the useless girl in a funny way. Similarly, a daughter is also presented as being worthless in No. CXXVI:

\section{No. CXXVI, pp. $175-176$}

\section{黄豆粒兒}

圆上圆

養活Ү頭不值錢

三塊豆腐二兩酒

送在婆婆大門口

婆婆說脚也大臉又醜

公公說留着罷留着罷

燒茶蓦飯也用他
The yellow haricot - is completely round - bearing a daughter, she is worth no money - just as much as two bits of bean-curd and two ounces of wine - when we send her to her mother-in-law's house - the mother-in-law says: her feet are large and her face is ugly - the father-in-law says: let her stay, let her stay! - she can be useful for boiling tea and cooking food.

In this song, a little girl with large feet and an ugly face is said to be without worth. Her being of little value is described in a vivid way in that she only costs as much as two bits of bean-curd and two ounces of wine. Even when she is used as a gift for someone, her defining characteristics are that she has large feet and an ugly face and her only function is to boil tea and cook meals for her husband's family. 


\section{The crying bride}

As described by Thomson, it was considered a barbarous custom for a woman to choose her future husband - her marriage should be settled by her parents or guardians. In addition, many marriages were known to lead to a lifetime of disappointment and tears. ${ }^{20}$ Indeed, as noted by Sheng, marriage in traditional Chinese society was "actually an issue of connecting the political, social, and economic resources between the two families, rather than a result of love and affection between the two married parties." ${ }^{21}$ According to a Chinese saying, a married-out daughter is

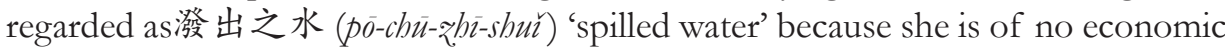
value to her birth parents. A woman was usually cut off from her natal family in a blindly-arranged marriage. ${ }^{22} \mathrm{~A}$ married daughter being specified as 'spilled water' can be seen in customary wedding day practices in many areas of China, including Hunan, Hubei, Shandong, Guangdong, and Jiangsu, in which the mother of the married daughter spills a basin of water when the daughter leaves her natal family. ${ }^{23}$ In addition, because when a woman marries she leaves her natal family and becomes part of her husband's family, Chinese brides are frequently found crying on their wedding days, as described in No. XLIII:

No. XLIII, pp. 65-66

新打一把茶囸亮堂堂

新買一個小猪兒不吃糠

新娶一個媳婦兒不吃飯

眼淚汪汪想他親娘
A newly made metal tea-kettle is very bright - a newly bought small pig does not eat husks of grain - a newly married wife does not take food - she weeps profusely and thinks of her mother.

In this song, the bride is weeping because she is homesick, even on the first day in her husband's family. The newly-bought pig perhaps implies that the little girl is a bought child bride. Interestingly, the parents of the bride may cry too, as seen in No. LIV:

${ }^{20} \mathrm{~J}$. Thomson, A bride and bridegroom [in:] Illustrations of China and Its People: A Series of Two Hundred Photographs, with Letterpress Descriptive of the Places and People Represented, vol. 2, London 1873.

21 X. Sheng, Chinese family [in:] Handbook of World Families, eds. B.N. Adams, J. Trost, Thousand Oaks, CA 2004, p. 102.

22 J.E. Stockard, Daughters of the Canton Delta: Marriage Patterns and Economic Strategies in South China, 1860-1930, Stanford, CA 1989, pp. 1-2.

23 Mao Li-Ping 毛立平,〈清代下層婦女與娘家的關係-以南部縣檔案為中心的研究〉(Lowerclass women and their natal families during the Qing period: A study based on the Nanbu county archive), 《近代中國婦女史研究》(Research on Women in Modern Chinese History) 2013, vol. 21, pp. 3-48. 


\section{No. LIV, pp. 83-84}

杜稆兒樹

開白花

養活Ү頭作甚麼

拿起剪子瞎嘎搭

嘎搭會了給人家

爹也哭

娘也哭

女婿過來勸丈母 丈母丈母你別哭 我家還有二斗穀 輾小米兒

謷豆粥

餓不死你的秃Y頭
The small pear-tree - has opened its white flowers - to bring to light a small girl - what is the use of it? - she begins first to take the scissors and cut badly the cloth - then when she has learned to cut the cloth, one must give her up to other people - the father also weeps - the mother also weeps - the bridegroom comes over to console his mother-in-law - and says: mother-in-law, mother-in-law, do not weep - I have got at home three pecks of grain - we will grind the oats - and boil a rice congee with beans - so that your bald-headed daughter shall not be starved to death.

In the above, the parents of the bride are weeping because their daughter is getting married and is leaving the family. It seems that while a married-out daughter was often referred to as 'spilled water,' a woman's ties to her natal family were not always severed during the Qing dynasty period. In an example presented by Lu, the bonds between a married-out daughter and her natal family (literati father) in the Qing dynasty remained strong, as shown by many extant letters and poems to each other. ${ }^{24}$ To conclude, while a married-out daughter in the Qing dynasty was considered to be like 'spilled water,' and would end up being part of her husband's family, the bonds between her and her natal family were not always weak.

\section{Domestic violence against women}

Domestic violence has long been a serious problem in China due to the influence of traditional Chinese society and ideas about a husband's dignity. In the Qing dynasty, a man was legally endowed with the power to discipline his wife, justifying serious violence by men against their wives. ${ }^{25}$ In Chinese Folklore: Pekinese Rhymes, such domestic violence is often described humorously, as can be seen in No. XIX:

24 W. Lu, A pear in the palm: A forgotten symbol of the father-daughter bond, "Late Imperial China" 2010, vol. 31, no. 1, pp. 62-97.

25 Jiao Jie 焦杰, 〈中国古代夫妻权力关系与家庭暴力〉(Chinese ancient marital power relations and domestic violence: To answer violence with violence on women in the Qing dynasty), 《陕西师范大学学报 (哲学社会科学版)》(Journal of Shaanxi Normal University (Philosophy and Social Sciences Edition)) 2017, vol. 46, no. 4, pp. 131-138. 


\section{No. XIX, pp. 32-34}

小二哥

吃飯兒多

吃完了飯

打老婆

打的老婆上窗户

窗户沒有檔兒

打的老婆照鏡兒

鏡子沒有底兒

打的老婆唱曲兒

曲兒沒有頭兒

打的老婆要猴兒

猴兒沒有圈兒

打的老婆銑天兒
The small second brother - eats too much - and when he has finished eating - he beats his wife - and the wife is so beaten that she jumps [up] on the window - the window has no bars - and the wife is so beaten that she looks in the mirror the mirror has no bottom - the wife is beaten so that she begins to sing - the song has no end - the wife is so beaten that she 'plays with the monkey' - the monkey has no circle - and the wife is so beaten that she springs up to the sky.

Indeed, in his description of Manchu ladies and marriage, Thomson observed that when a woman married herself into a Manchu family, she was subject to her new parents' rule, and her husband and mother-in-law would often beat her if she neglected her duties as "general domestic drudge." 26 In Chinese Folklore: Pekinese Rhymes, moreover, a woman may be beaten by her father-in-law and is not allowed to fight back according to the etiquette of the established social order, as shown in No. CXXXIV:

\section{No. CXXXIV, p. 183}

豆芽菜

水淜淜

誰家的媳婦兒打公公

公公拿着柺棍兒拐

媳婦兒拿着袖口兒甩
The bean sprouts - are dripping with water - who is the wife who dares to beat her father-in-law? - the father-in-law beats her with his stick - and the woman only lets her sleeve down (with anger).

In a nutshell, as the above two rhymes show, Chinese women suffered from serious domestic violence during the late Qing period. This is presented in Chinese Folklore: Pekinese Rhymes in a humorous manner.

${ }^{26} \mathrm{~J}$. Thomson, Manchu ladies and a Manchu marriage [in:] Illustrations of China and Its People: A Series of Two Hundred Photographs, with Letterpress Descriptive of the Places and People Represented, vol. 4, London 1873. 


\section{A disobedient woman deserves negative consequences}

In the traditional Chinese family, a woman should obey the Three Obediences and the Four Virtues. Accordingly, when she becomes a wife, she should be obedient to her husband. In addition, she should be submissive, restrained in speech, dress and adorn herself to please her husband, and properly and cheerfully manage the household. ${ }^{27}$ While this does not mean that all Chinese women obeyed the Three Obediences and the Four Virtues, those who failed to do so faced negative consequences, as can be seen in No. LXXXIX and No. LXXXII:

No. LXXXIX, pp. 125-126

\section{黑老婆兒 \\ 满地滚 \\ 嗔着他男人不買粉 \\ 買了粉他不搽 \\ 嗔着他男人不買菻 \\ 買了菻他不打 \\ 嗔着他男人不買馬 \\ 買了馬他不揋 \\ 嗔着他男人不買匮 \\ 買了匮他不盛 \\ 嗔着他男人不買繩 \\ 買了繩他上吊 \\ 嚇了他男人一大跳}

The old brown woman - rolls herself all over the ground scolding [him] because her husband does not buy cosmetic [s] for her - but when he has bought cosmetic[s] then she does not use it [them] - scolding because her husband does not buy hemp for her - when he has bought hemp, then she does not thrash [thresh] it - scolding because her husband does not buy a horse - when he has bought a horse, she does not feed it - scolding because her husband does not buy a wardrobe - when he has bought the wardrobe, she does not put her things there - scolding because her husband has not bought a cord - when he has bought a cord, she hangs herself - and frightens her husband to death.

As can be seen in No. LXXXIX, the old brown woman is not submissive at all - she is constantly scolding her husband for not satisfying her. In addition, this woman is described as having dark skin, which is regarded as a negative trait in the late Qing period. In describing how a lady's maid pays attention to her complexion, Thomson observed that even the poorest women in China did not want to be tanned, and nor did men during that period: "It is wonderful to notice how careful the poorest women in China are of their complexions, how they dread being tanned by the sun, and how universally the fan is employed as a sunshade (...) Even the men delight in a pale skin, and may be seen during summer wearing the fan spread out to shade the face, and fixed to the head by means of the tail."28

As such, this woman's dark skin perhaps implies that she does not take care of her looks and is not able to please her husband.

\footnotetext{
27 Berkshire Encyclopedia of China...

28 J. Thomson, The lady's maid [in:] Illustrations of China and Its People: A Series of Two Hundred Photographs, with Letterpress Descriptive of the Places and People Represented, vol. 1, London 1873.
} 
No. LXXXII, pp. 105-106

香爐兒

瓦燈臺

爺㕮兒娶了個奶奶兒來

不梳頭

不作活

嘴镜手懶竟愛喝

爺爺兒没法兒治

氣的竟哆嗦

說我打你這個拙老婆
An incense-stove and an earthenware lamp - the gentleman has married a lady - who does not comb her hair - does not work - is gluttonous and lazy and likes nothing but drinking the husband has no way of correcting her - and is so angry that he trembles - and says: I will beat you stupid old woman!

In No. LXXXII, the woman does not dress and adorn herself to please her husband. Instead of managing the household, she is lazy and likes drinking. As a result, both women are presented as needing to face negative consequences for their actions. While the woman in No. LXXXIX hangs herself, the woman in No. LXXXII is to be beaten by her husband - both cases are presented in a humorous fashion.

\section{Being a mother}

In 2011, Amy Chua, a law professor in the USA, published a controversial book on how Chinese parents raise their children. ${ }^{29}$ She called herself a "Tiger Mother," as in traditional Chinese culture, a tiger symbolizes strength and power and thus inspires fear and respect. However, as mentioned previously, the concept of 'tiger' in Chinese assumes negative connotations for women, as women should not be powerful and violent. ${ }^{30}$ Although the image of a Chinese mother during the late Qing period is not presented in Chinese Folklore: Pekinese Rhymes, the desire of women to have children is emphasized. In fact, becoming a mother was considered to be extremely important for Chinese women during the imperial period. More specifically, a wife needed to give birth to a son to carry on the family line of her husband. In No. LXXXIV, the desire of a woman to have a child is seen and in No. LXXVI a woman without a child is described in a sarcastic way:

29 A. Chua, Battle Hymn of the Tiger Mother, New York 2011.

30 S.-F. Chen, L.-C. Chen, What animals reveal... 
No. LXXXIV, pp. 119-121

高高山上有個小廟兒

裹頭住着個神道兒

頭戴草帽兒

身穿藍罩兒

腿穿皮套兒

腰繫草要兒

四個小鬼抬轎兒

兩個小鬼

[口溫]兒哇[口溫]兒哇吹號兒 解南來了一個青春年少兒

手裹提溜千張元寶雨吊兒

進廟兒

求個懷抱兒

點把火

灰兒花兒燒你的小廟兒

神道兒聞聽心好惱

呌聲小鬼發票兒

快拿青春年少兒

嚇的青春年少兒

咕嘟咕嘟冒泡兒
On a very high mountain - there is a small temple inside is sitting a holy man - who wears on his head a dry grass hat - and on his body an azure cloak - and on his legs skin leggings - and round his waist a grass rope for [a] girdle four small devils bear the chair - two small devils blow the trumpet - from the South [south] has come a young girl in the bloom of life - who has in her hands a paper ladder and paper money - she enters the temple - to pray for a child (she says:) give me a child and it shall be all right - if you do not give me a child - I will make a fire - and burn your small temple - the holy man hearing this is very much angry - and calls for the small devils to issue a warrant of arrest - (saying) quickly apprehend this young woman in the bloom of life, but the young woman in the bloom of life is so scared that she gasps for breath.

\section{No. LXXVI, pp. 108-110}

\author{
高高山上一座樓 \\ 雨個姑娘去梳頭 \\ 大姐梳的盤龍䯽 \\ 二姐梳的賽花樓 \\ 三姐沒的梳 \\ 一梳梳了個獅子滚紼手 \\ 大姐坐的是金板登 \\ 二姐坐的是銀板登 \\ 剩下三姐沒的坐 \\ 一坐坐在一盤磨 \\ 大姐抱着個金娃子 \\ 二姐抱着個銀娃子 \\ 三姐沒得抱 \\ 一抱抱着個樹磕权
}

On a very high mountain there is a high tower - two girls go there to comb their hair - the eldest sister combs her hair into a 'coiled dragon chignon' - The second sister combs her hair into a 'rivaling flowers tower chignon' - the third sister has no other way of combing her hair - and combs it in a ruffled way - the first sister sits on a golden stool - the second sister sits on a silver stool - there remains the third sister who has no room to sit - and sits on a stone-mill - the first sister folds in her arms a golden baby - the second sister in her arms a silver baby - the third sister has nothing to fold in the [her] arms - and folds a forked branch.

A woman wants to have a child of her own and a mother's love is not always reserved for the child of another woman. As can be seen in No. XIII, a child without a biological mother is described as being like a 'small cabbage' and not being taken good care of. When his father marries another woman and has another child, he is mistreated. The last line suggests that the stepmother is not as good as his birth mother. 
No. XIII, pp. 22-23

小白菜兒

地裹黄

七八歲兒

離了娘

好好兒跟着爹爹過

又怕爹爹娶後娘

娶了後娘三年整

養了個兄弟比我强

他吃菜

我泡湯

哭哭啼啼想親娘
Like the small cabbage - which has become yellow and dry on the ground - at the age of seven or eight years, I have lost my mother. - I lived so well near my father - only I was afraid he would take another wife - and he has taken her; just after three years - they have given me a brother who is more worthy than I am - because he eats the food - and I only may pour the gravy on my rice - weeping and wailing I think of my own mother!

In addition, according to the Three Obediences, a woman should be obedient to her $\operatorname{son}^{31}$ and because of this a mother may be mistreated by her son. No. LX is a monologue by a mother whose son neglects her needs after marrying his wife.

喜雀尾巴長
娶了媳媂兒不要娘
媽媽要吃窩兒薄脆
沒有閒錢補笑籬
媳婦兒要吃稆
備上驢
去趕集
買了稆
打了皮
媳婦兒媳婦兒你吃梨
No. LX, pp. 92-93

The magpie has a long tail - after he has taken a wife he no more wants his mother - when his mother wants to eat some cheap cake - then (he says) 'there is no idle money to mend willow spoons' - when his wife wants to eat pears - then he gets ready his ass - and goes to the market - when he has bought the pears - he peels them - and asks [his] wife, wife, will you eat pears?

To sum up, during the late Qing period it was extremely important for a woman to become a mother as a Chinese wife needed to have a son to carry on the family line of her husband. However, not all mothers were good to their children, especially stepmothers. In addition, when a woman gets old, she may be mistreated by her son. All these aspects are presented humorously in Chinese Folklore: Pekinese Rhymes.

31 Berkshire Encyclopedia of China... 


\section{The hierarchy among women}

In modern society, men tend to demonstrate hierarchy in their interactions with other men, whereas women are frequently found to show solidarity with other women. ${ }^{32}$ However, a hierarchy among women within the Chinese family was seen during the Qing dynasty.

No. CLVI, pp. 202-204

大娘二娘猜

三娘, 駡我醜奴才

我也不是偷來的

我也不是跑來的

花紅綠轎兒娶來的

瞧㫿奴家的手

金珠瑪瑙一大斗

瞧㫿奴家的牙

從小兒愛喝個菓子茶
The first wife and the second wife play at guessing riddles the third wife insults me as 'an ugly slave' - but I did not come here stealthily - nor did I run away to come here - I was married and taken here in a red chair and was followed by [a] green chair - looks [look] here at my hands! - I could fill a big peck with the gold pearls and cornelion [carnelian] that I wear - look here at my teeth! - since I was a child I have been accustomed to take 'tea with candied fruits.'

\section{No. XXIII, pp. 38-39}

\section{樹葉青}

呀呀兒英

我跟姐姐過一冬

姐姐蓋着花花被

妹妹蓋着羊皮睡

姐姐穿着紬子襖

妹妹穿着破皮襖

姐姐戴着金穊子

妹妹戴着竹圈子

姐姐騎着高頭馬

妹妹, 騎着樹喀权

姐姐登着銀鐙兒

妹妹登着牆縫兒

姐姐抱着個銀娃娃

妹妹抱着個癩蛤麻

走一步來哇兒呱哇兒呱又哇兒呱
The tree leaves are dark - I spend a [the] winter with my older sister - my elder sister covers her bed with a coverlet embroidered with flowers - and I, the younger sister, cover my bed with a goat skin - my elder sister wears a satin overcoat I, the younger sister, wear a broken skin overcoat - my elder sister wear golden hair-pins - and I, the younger sister, wear bamboo ear-rings - my elder sister rides on a splendid horse and I, the younger sister, ride on a forked branch - my elder sister leans her feet on silver stirrups - and I, the younger sister, lean my feet on the wall crevices - my elder sister holds in her arms a silver baby - and I, the younger sister, hold in my arms a scabby toad - which moves a step and then cries kurkuàkurkuà.

As the above two rhymes show, hierarchy among women in the Chinese family during the late Qing period was quite evident. In No. CLVI, the hierarchy concerns wives in a family, while in No. XXIII, the hierarchy concerns two sisters. As the two rhymes suggest, the youngest woman had the lowest status of all.

32 L.-C. Chen, Taiwanese and Polish Humor: A Socio-Pragmatic Analysis, Newcastle upon Tyne 2017. 
Interestingly, although there seems to be no hierarchy among women in modern society, as they tend to be more cooperative in their interactions with other women, ${ }^{33}$ there still seems to be a hierarchy among sisters. More specifically, in various cultures, younger sisters still face greater challenges than first-born sisters for a variety of reasons. ${ }^{34}$

\section{The practice of foot-binding among women}

The bound feet of Chinese women were once considered a symbol of high status and a mark of beauty, referred to as 三寸金蓮 (sän-cùn-jīn-lián) 'the three-inch golden lilies.' The practice of foot-binding not only reflected how men saw women and their sexual preference, but also forced women to cage themselves indoors. ${ }^{35}$ The subject of bound feet also appeared in Chinese Folklore: Pekinese Rhymes, as seen in No. LXXVIII and No. LXXV:

No. LXXVIII, pp. 111-112

你媽七

我媽八

你媽小脚兒開黄花

左一盤兒

右一盤兒

你媽肚子裹有小孩兒

多大了

曾走了

你媽肚子裹又有了
Your mother 'seven' - your mother 'eight' - your mother has small feet - a tour to the left - and a tour to the right - your mother is in a family way - 'how old is the baby?' - 'he can walk' - your mother is again in a family way.

\section{No. LXXV, pp. 107-108}

小脚兒娘

愛吃糖

沒錢兒買

搬着小脚兒哭一塲

The little lady with the small feet - likes to eat sugar - but has no money to buy it - and sits cross-legged and weeps for a good while.

As Thomson observed, foot-binding among Chinese women was considered an essential element of female beauty and resulted from man's selfish jealousy, in the

33 J. Coates, Women, Men and Language, Harlow 2004.

34 D. Tannen, You Were Always Mom's Favorite! Sisters in Conversation throughout Their Lives, New York 2009.

35 F. Hong, Footbinding, Feminism, and Freedom: The Liberation of Women's Bodies in Modern China, London/Portland, OR 1997. 
sense that women were not to be trusted and should be crippled. ${ }^{36}$ When describing the small feet of an Amoy lady whom he photographed, Thomson argued that her bound feet did not look good, nor did they smell good: "And yet, had I been able, I would rather have avoided the spectacle, for the compressed foot, which is figuratively supposed to represent a lily, has a very different appearance and odor from that most beautiful and sacred of flowers." 37

In 1903, Jin Tianhe (1873-1947) published China's first feminist manifesto, entitled The Women's Bell, in which he suggested that leucorrhea in Chinese women was caused by the practice of foot-binding. ${ }^{38}$ Although there was no judgment made on the practice of foot-binding among Chinese women in Chinese Folklore: Pekinese Rhymes, the above two rhymes present these women's lives in a humorous way.

\section{The shrew, the unchaste woman, and the carefree woman}

Three interesting rhymes about women during the late Qing period are found in Chinese Folklore: Pekinese Rhymes. In No. XCIV, a wife is presented as a shrew; in No. CXI, it is implied that a wife is having an affair with her neighbor; and in No. XV, a woman chooses not to get married so as to lead a happier life.

小秦椒兒

怎麼不辣

我爸爸瞧見我媽就害怕

跪在地下頂着個燈

還怕流了油兒摔了蠟

我媽要洗脚

我昘往前跑

脫了襙子還說香

要是說臭挨嘴巴

裝過袋烟兒

彪過碗茶兒

樂的我媽咨着牙兒

我爸爸呌了一聲孩兒他媽

老太太兒饒了我罷

再要生氣我滚出去

從今兒永遠我不问家
No. XCIV, pp. 131-133

The small chillies [chilies] - how could they not be bitter? when my father catches sight of my mother, he is afraid - he kneels down with a lamp on his head, - and is also afraid lest the oil should run down, or the candle should fall - when my mother wants to wash her feet - my father runs forward when he has taken down the socks he says that it is scented if he says it is bad [foul] smelling he gets a slap on the face when he has filled her pipe - and handed over to her a cup of tea - my mother is so delighted that she shows her teeth - my father has once called her: o mother of my children - old lady, forgive me, now - if you are going to get angry again, I will roll away - and from now henceforward I will never come back home.

\footnotetext{
36 J. Thomson, A bride and bridegroom...

37 J. Thomson, Small feet of Chinese ladies [in:] Illustrations of China and Its People, vol. 2.

38 Jin Tianhe 金天㬏, 《女界钟》(The Women's Bell), Shanghai 1903, p. 31.
} 
The above rhyme is a narrative by a child, in which the child's mother is feared by his/her father. Interestingly, the two types of address forms for father in Mandarin are used in this song: 爸 (ba) and 爹 (diē). According to Guo, although the use of bà to refer to 'father' appeared quite early on, it was rarely used until the Qing dynasty. ${ }^{39}$ As Guo has further argued, although this form of address can be found in many literary works in the Qing dynasty, it was not as common as other address forms for father. Its use flourished after the advent of the National Language Movement ${ }^{40}$ and, even though this address form was frequently used in Beijing dialect, its appearance was quite late. ${ }^{41}$ As such, it seems that the rhyme appeared quite late on in the late Qing period.

No. CXI, pp. 150-152

月亮爺
亮堂堂
開開後門兒洗衣裳
洗得白奬得白
娶了個媳婦兒
不存財
愛喝酒
愛㺺牌
燒餅麻花兒一大落
黑䴴火燒
雨大鈛個
隔壁兒倒有
姜三哥
也會過
綠靴子
綠帽子
綠袍子
綠套子

The father moon - it so bright! - I open the back door to wash my linen - I wash it white and I starch it white - but (my husband) after having married me - is thrifty with his money - he likes to drink wine - he likes to play cards - (and likes too) a great pile of cakes and buns - and brown flower biscuits - which cost two big $\underline{\text { cash }}$ [coins] each - but here living by us - there is a neighbor, Chiang the third - who knows how to live well - because he has got green boots and a green hat - and a green garment - and a green jacket.

In feudal society, a woman's chastity was regarded as being more important than her life, particularly during the Qing dynasty. However, in the above rhyme, the wife is not satisfied with her husband and compares him to their neighbor Chiang the third. Although the wife's affair is not clearly described, the phrase 'green hat'

39 Guo Xi 郭熙, 〈对汉语中父亲称谓系列的多角度考察〉(A comprehensive observation of Chinese address forms for “father”), 《中国语文》(Zhongguo Yuwen) 2006, vol. 2, pp. 166-173.

40 國語運動 (guóyúyùndòng) 'The National Language Movement' was a social and cultural movement launched to promote a standard Chinese language from the late Qing period to the Republic of China. Its two slogans were: 國語統一 (guóyǔtóngyz̄) 'Reunification of National Language' and 言文一致 (yánwényízhi) 'Consistency of Speech and Writing.'

41 Guo Xi 郭熙, 〈对汉语中父亲称谓系列的多角度考察〉(A comprehensive observation)... 
is an expression for a woman having an affair with a man in Mandarin and green is the color used metaphorically to refer to a woman cheating on her husband. According to Lang Ying's (1487-1566) Qi Xiu Lei Gao, a prostitute's husband would wear a green kerchief to distinguish himself from other men during the Spring and Autumn Period (771-476 BC), and thus a green kerchief came to symbolize humiliation in ancient China. ${ }^{42}$

$$
\text { No. XV, pp. 25-26 }
$$

日頭出來一點紅 師傅騎馬我騎龍 師傅騎馬遶街走 我騎青龍過海東 海束有我家

我家種着五盆花 大姐愛個紅苟藥 二姐愛個牡丹花 三姐愛的是桃花瓣 四姐愛的是大蓮花 剩下五姐無的愛 一心要出家 出家人兒樂陶陶 一來不受公婆氣 二來不受丈夫謷 三來懷中不抱子 四來散淡又逍遙
The sun has come out like a red spot - my teacher rides on a horse and I ride on a dragon - the teacher riding on the horse goes along the streets - I ride on the dark dragon cross over to the East [east] of the sea - at the East [east] of the sea there lives my family - and in my family they cultivate five flower-pots - my first sister likes the red peony - my second sister like the petals of the peach blossoms. - There is the fifth sister who has nothing she may like - and does not think of other but becoming a nun - the women in the monastic life live very happily indeed - firstly they do not suffer the vexations of [the] father-and mother-in-law - second, they do not suffer a husband's maltreatment - thirdly, they do not bear children - and fourthly, they live freely and in a condition of blissful peace.

In this rhyme, being a nun makes a woman happier than getting married, as she will not suffer mistreatment from her parents-in-law and the husband. In addition, she will enjoy a carefree life without children.

To conclude, perhaps as a result of rising feminism during the late Qing period, not all wives were as obedient to their husbands as before; some of them behaved 'shrewishly' and were feared by their husbands. They did not always remain chaste for their husbands either. In addition, getting married was not the only option for women anymore. While many songs in Chinese Folklore: Pekinese Rhymes show women's unwillingness to get married, their miserable lives after getting married, and the importance of having children, interesting songs displaying oppositional attitudes are also observed. In other words, the songs show that some women during the late Qing period started to focus on their own needs.

42 Lang Ying 郎瑛, 《七修類稿》(Qi Xiu Lei Gao). See https://ctext.org/wiki.pl?if=gb\&res= 118164\&searchu=綠頭巾. 


\section{Conclusion}

With the ideals of the Confucian patriarchy holding strong within the Chinese mind for thousands of years, Chinese women's subordination was especially reinforced during the Qing dynasty. However, the modern ideals of feminism also arose thanks to the reformist movement, and the establishment of Church schools to educate Chinese women. As such, analyzing how women in the late Qing period were described is most interesting, as traditional Chinese social values and rising feminism co-existed at the same time. Guido Amedeo Vitale's Chinese Folklore: Pekinese Rhyme reveals the lifestyles of Chinese people in Peking (Beijing) during the late Qing period, including those of women. The songs reveal various aspects of women's lives at that time.

First, we can find songs that deal with discrimination against daughters, as daughters were regarded being useless and worthless. Next, brides are shown to cry on their wedding days and married-out daughters are compared to 'spilled water.' Furthermore, women are frequently shown to suffer from domestic violence after getting married. Moreover, women were expected to be obedient. If they were not obedient, they would suffer negative consequences. Also, being a mother was the important thing for most women, but a mother's love was not always reserved for a stepchild. In addition, there were hierarchies among women, such as among wives in a family or among sisters. Next, the practice of foot-binding among women is also presented in many songs. Finally, due to the rise in feminism during the late Qing period, women are presented as not being as obedient as before and starting to focus on themselves.

To sum up, Chinese Folklore: Pekinese Rhyme provides an abundant resource for observing Chinese women's lives, attitudes, and treatment during the late Qing period. While the Three Obediences and the Four Virtues for women dominate in the songs, changes can still be observed, which mark the start of small progress in acknowledging the rights of Chinese women.

\section{STRESZCZENIE}

\section{OBRAZ CHIŃSKICH KOBIET PÓŹNEGO OKRESU QING W CHINESE FOLKLORE: PEKINESE RHYMES GUIDO AMEDEO VITALE}

Idee konfucjańskiego patriarchatu zajmowały chińskie umysły od tysięcy lat. W epoce Qing podległość kobiet pogłębiła się przez rozpowszechnione praktyki krępowania stóp, prostytucję, konkubinat, dzieciobójstwo dziewczynek oraz wywieraną na wdowy presję społeczną, by pozostawały wierne zmarłym mężom. Jednocześnie kobiety okresu Qing nie tylko wy- 
pełniały zasady konfucjańskie, ale także, poprzez codzienne praktyki, przekształcały konfucjańskie nauczanie tak, aby wzmocnić swoja pozycję w domowych wnętrzach, tworząc osobiste znaczące światy. W tym czasie rodził się także chiński feminizm zapoczątkowany przez działania ruchu reformistycznego i szkoły przykościelne. Kwestie roli i miejsca chińskich kobiet oraz ich zmagania życiowe były szeroko badane z perspektywy różnych dyscyplin, jednak niewiele badań zajmuje się zagadnieniem chińskich kobiet w literaturze. Poprzez analizę wierszy zebranych przez Guido Amadeo Vitale w Chinese Folklore: Pekinese Rhymes [Chiński folklor: Pekińskie wersy], które w licznych scenach przedstawiają życie, zachowania oraz przykłady traktowania kobiet w późnym okresie Qing, w artykule ukazano, że pomimo ciągłej dominacji zasad Trzech Posłuszeństw i Czterech Cnót w życiu kobiet można zaobserwować zmiany będące pierwszymi krokami do postępu. 